\begin{tabular}{|l|l|l|}
\hline \multicolumn{2}{|c|}{ PublisherInfo } \\
\hline \hline PublisherName & $:$ & BioMed Central \\
\hline \hline PublisherLocation & $:$ & London \\
\hline \hline PublisherImprintName & $:$ & BioMed Central \\
\hline \hline
\end{tabular}

\title{
Anthrax stifles dendritic cells
}

\begin{tabular}{|l|c|l||}
\hline \multicolumn{2}{|c|}{ ArticleInfo } \\
\hline \hline ArticleID & $:$ & 4814 \\
\hline \hline ArticleDOI & $:$ & $10.1186 /$ gb-spotlight-20030717-02 \\
\hline \hline ArticleCitationID & $:$ & spotlight-20030717-02 \\
\hline \hline ArticleSequenceNumber & $:$ & 166 \\
\hline \hline ArticleCategory & $:$ & Research news \\
\hline ArticleFirstPage & $:$ & 1 \\
\hline \hline ArticleLastPage & $:$ & 2 \\
\hline \hline & & RegistrationDate : 2003-7-17 \\
\hline ArticleHistory & $:$ & OnlineDate \\
\hline \hline ArticleCopyright & $:$ & BioMed Central Ltd2003-7-17 \\
\hline \hline ArticleGrants & $:$ & \\
\hline \hline ArticleContext & $:$ & 130594411 \\
\hline \hline
\end{tabular}




\section{Tudor Toma}

Email: t.toma@imperial.ac.uk

Bacillus anthracis, the causative agent of anthrax, can cause immunosuppression with uncontrolled bacteraemia, multisystem dysfunction, and, ultimately, death. The critical virulence factor of $B$. anthracis is lethal toxin (LT), which affects many cell types, including macrophages. The interaction between $B$. anthracis components and dendritic cells results in the activation of immune suppression mechanisms, but the precise nature of these systems has been unclear. In the July 17 Nature, Anshu Agrawal and colleagues at the Emory Vaccine Research Center show that LT impairs the function of dendritic cells and host immune responses by disrupting MAP kinase signaling (Nature 2003, 424:329-334).

Agrawal et al. used mouse splenic dendritic cells exposed to LT in vitro and in vivo. They observed that when stimulated with lipopolysaccharide, dendritic cells did not upregulate costimulatory molecules, secreted greatly diminished amounts of proinflammatory cytokines, and did not effectively stimulate antigen-specific T cells in vivo. Injections of LT into mice induced a profound impairment of antigen-specific T- and B-cell immunity. In addition, they showed that LT caused impairment of phosphorylation of p38 and ERK1/2, which mediates the suppressive effects on dendritic cells.

"These data suggest a role for LT in suppressing host immunity during $B$. anthracis infections, and represent an immune evasion strategy, where a microbe targets MAP kinases in dendritic cells to disarm the immune response... LT or its derivatives may also represent potential therapeutic tools in the regulation of deleterious immune responses in autoimmunity or transplantation," conclude the authors.

\section{References}

1. Anthrax toxins and the host: a story of intimacy

2. Macrophage apoptosis by anthrax lethal factor through p38 MAP kinase inhibition

3. Nature, [http://www.nature.com/nature]

4. Emory Vaccine Research Center, [http://www.emory.edu/WHSC/YERKES/VRC/] 